\title{
Social Campaign on Protection of Endemic Animal Protection in North Maluku through Social Media
}

\author{
Fauji Ilyas \\ \{faujiodjie@gmail.com\} \\ Universitas Diponegoro, Indonesia
}

\begin{abstract}
Aketajawe National Park - Lolobata (TNAL) of North Maluku is designated as one of the conservation areas in Indonesia because it has an important role in preserving the living natural resources and the uniqueness of its ecosystem. With the legal protection of endemic endangered species of birds that are almost extinct, will minimize poaching and illegal trade that is rife. This study uses a qualitative descriptive approach to illustrate how campaign strategies are carried out through social media in an effort to protect the uniqueness of endemic rare bird ecosystems in Maluku. This study found that the efforts of social campaigns using social media carried out by the North Maluku Aketajawe National Park Conservation Center were carried out with the \#conservasitamannasional national slogan. The idea came out as a result of social reality that occurred about the events that occurred and other matters relating to endemic animal protection. The discourse they convey is given the hashtag (\#) or the term is hashtag. This research argues, to change in this situation, it is demanded to change the pattern of social campaigns carried out by adjusting the level of penetration of social media users in the North Maluku area.
\end{abstract}

Keywords: Campaign, Social Media, Protection, Endemic Bird Species.

\section{Introduction}

Indonesia has many endemic bird species, one area that has endangered endemic animals is North Maluku. Like ternate Kasturi birds, white parrots, and various species of parrots. Endemic rare bird species that exist in North Maluku from year to year have decreased population, this is caused by several factors, including illegal trade.

Various cases of acts of violence against animals lately often occur. The most recent case that has caught the attention of the people of North Maluku is the case of the trade in rare wild birds. As many as 85 protected birds were confiscated from a number of areas in North Maluku Province. These animals were secured in a joint operation to act against the circulation of wild plants and animals carried out by the Papua Maluku Regional Environmental and Forestry Law Enforcement and Enforcement Agency together with the Maluku Provincial BKSDA Conservation Section I Ternate and North Maluku Regional Police on 20 September 29 2019. The protected birds and confiscated evidence included: Kasturi Ternate (Loriusgarrulus) 49 tails, White Cockatoo (Cacatuaalba) 15 tails, Parrot (Eclectusroratus) 11 tails, Purple Parrot Neck (Eossquamata) 10 tails [1].

Actually, the government also does not remain silent about cases of acts of violence against animals that lately rampant occur. This can be seen from the issuance of recognition of 
the importance of animal welfare in Act Number 18 of 2009 which was revised to Act Number 41 of 2014 concerning Animal Husbandry and Health.

The law states that animal welfare is all matters related to the physical and mental state of animals according to the size of the animal's natural behavior that needs to be applied and enforced to protect 10 animals from any improper treatment of animals used by humans.

Law number 5 of 1990 concerning the conservation of biological natural resources and their ecosystems has also regulated the prohibition on catching, damaging endemic species of endangered species. Article 21 of the law states that everyone is prohibited from:

a) Capture, injure, kill, store, possess, care for, transport, and trade protected animals in a state of life;

b) Storing, possessing, maintaining, transporting and trading protected animals that are dead;

c) Removing protected animals from one place in Indonesia to other places inside or outside Indonesia;

d) Take, destroy, destroy, trade, store or have eggs and or nests of animals protected.

Furthermore, if the provisions in the article above if violated, then it is considered a criminal offense as stated in Article 40 paragraphs 2.4, and 5, which states:

a) Whoever intentionally violates the provisions referred to in Article 21 paragraph (1) and paragraph (2) and Article 33 paragraph (3) shall be sentenced to a maximum imprisonment of 5 (five) years and a maximum fine of Rp. 100,000,000.00 (one hundred million rupiah);

b) Anyone who for his negligence violates the provisions referred to in Article 21 paragraph (1) and paragraph (2) and Article 33 paragraph (3) shall be liable to a maximum imprisonment of 1 (one) year and a maximum fine of Rp. 50,000,000.00 (fifty million rupiah);

c) The criminal act as referred to in paragraph (1) and paragraph (2) is a crime and the criminal act as referred to in paragraph (3) and paragraph (4) is a violation.

The problem of incidents of violence against animals has reached the point of concern. Where there must be a solution as soon as possible before more and more other events are more severe. The solution to the problems associated with acts of violence against animals is that efforts must be made to appeal and provide information to the public regarding the protection of endemic animals protected by law. Therefore, social campaigns are the right media or means. because in this way information will be easily reached and understood by the public so that there are no more cases of acts of violence against other animals. According to what has been explained above that the solution to the problem of incidents of violence against animals is through social media campaigns. The social campaign here aims to provide an appeal to the community not to hurt animals, provide information to the public about the impact that will result if hurting animals and provide understanding to the community if hurting animals is unlawful.

From this incident, it is necessary and important to hold an appropriate campaign to raise public awareness of the importance of respecting and understanding the welfare of endemic endangered species in North Maluku. Communication media is a container or means in the field of communication. This communication media is also an object or tool that is used as an intermediary for campaigning. Communication media plays an important role in influencing changes in society. Communication media are means or tools that channel communication messages conveyed by someone to others, for example telephone, electronic mail, radio, television, computers using a network that is connected to the modem [2]. 
Moreover, with technological advances like now it can facilitate someone in carrying out social campaign activities using social media. The power of social media to influence society is based exclusively on its social aspects so it is deemed necessary to utilize social media to carry out social campaigns. The campaign is basically the delivery of messages from the sender to the audience. This research illustrates how the campaign strategy carried out by the North Maluku Aketajawe - Lolobata National Park (TNAL) through social media in an effort to protect the uniqueness of endemic rare bird ecosystems in North Maluku.

\section{Research Method}

Using a qualitative approach that is descriptive in nature, research that makes systematic, factual and accurate descriptions of the facts and characteristics of research subjects. In this study researchers used the evaluation method. Colgate \& Danaher [3] explain that evaluation is a systematic study that combines and explains the implementation, effects, basis and social implications of a policy or program. Evaluation can help institutions in selecting, monitoring and improving policies and programs. In this study, data collection was done by collecting documents and in-depth interviews with informants through a question and answer process directly.

\section{Result and Discussion}

Campaign in principle is a process of communication activities of individuals or groups carried out in an institutionalized and aims to create a certain effect or impact. Rogers and Storey [4] define campaigns as "a series of planned communication actions with the aim of creating a certain effect on a large number of audiences carried out sustainably over a certain period of time". Some communication experts recognize that the definition given by Rogers and Storey is the most popular and acceptable among communication scientists. This is based on two reasons. First, the definition clearly states that the campaign is a form of communication actions, and the second reason is that the definition can cover the entire process and phenomenon of campaign practices that occur in the field.

Referring to the definitions above, we can see that in every communication campaign activity it contains at least four things, namely campaign actions aimed at creating certain effects or impacts, large number of target audiences, concentrated in a certain period of time, and through a series of actions organized communication.

In addition to the four main features above, a campaign also has other characteristics or characteristics, namely a clear source, the initiator, designer, deliverer and person in charge of a campaign product (campaign makers), so that each individual who receives a campaign message can identify or evaluate the credibility the source of the message at any time.

In addition, campaign messages are also open for discussion, even the main ideas underlying the campaign are open for criticism. Openness like this is possible because the ideas and objectives of the campaign basically contain good for the public. All actions in campaign activities are based on the principle of persuasion, which invites and encourages the public to accept or do something recommended on the basis of volunteerism. Thus, the campaign in principle is an example of actual persuasion. In the expression Perloff [5] it says "Campaigns generally exemplify persuasion in action". [6]. While the understanding of the 
social campaign itself is an activity campaigning to communicate messages that contain about social problems, and non-commercial.

Social campaign is a communication process carried out to disseminate important messages that are needed by the community. Admittedly, there are many innovations, ideas, ideas, which are social in nature, important to convey to the public. For example, the idea of protecting natural ecosystems includes the protection of endangered species protected by law. To support the campaign so that it is easily accepted and understood by the public, appropriate media is certainly needed. The media should be media that are easily seen and found in people's daily lives. The development of increasingly sophisticated technology has now begun to be put to the best use by the Aketajawe National Park - Lolobata (TNAL) of North Maluku for social campaign facilities.

"In the process of social campaigns related to anti-violence against animals, it is divided into two main media namely through brochures, books, leaflets and also through social media through Facebook, Instagram and Twitter", (Jumrin Said, Head of Section I of the National Park Management in the Aketajawe Lolobata National Park Office, interview).

In general, all types or forms of communication campaigns always use the media as a channel for sending messages that has been well laid out to the audience that was planned in advance. According to Weiss \& Tschirhart (1994) in Venus [6], the purpose of a campaign cannot but if it wants to achieve certain changes, certain changes, changes in attitudes and behavior of a large number of individuals who will be targeted by the campaign [7]. Changes in individual attitudes and behavior are the outcomes of the campaign which at the same time can initiate attitudes and family behavior changes, groups in society and even the wider community.

At present the use of new media for social movements is increasing, because new media is considered to be a tool for change and democracy. Lim in Hapsari [8] states that social movements in new media tend to be fast, lean and numerous. At the ideological level, interactivity has become one of the added value characteristics of new media. Where the old media offers passive consumption, while the new media offers interactivity. This is one of the keys why new media can be used to drive a change (social movements). As is the case with the social campaign movement carried out by the North Maluku Aketajawe National Park Lolobata (TNAL) on social media. This social media has provided space for the public to engage in interactivity and collective movements in providing their views.

The campaign movement through social media carried out by the North Maluku Aketajawe - Lolobata National Park (TNAL) was present as a forum for the community to participate in preserving biodiversity of endemic animals by carrying out the \#conservasitamannasional slogan. The idea came out as a result of social reality that occurred about the events that occurred and other matters relating to endemic animal protection. The discourse they convey is given the hashtag (\#) or the term is hashtag. Hashtag is a word without spaces that starts with the \# symbol.

"Those in social media are creative and dynamic communities, because of that the role of the hashtag has changed from being just a marker of a particular topic to a symbol for movement. Social movements that are gathered in \# ....as a form of invitation to participate in preserving the sustainability of natural resources and to protect the fate of protected animals in the future" (Jumrin Said, Head of Section I of 
the National Park Management in the Aketajawe Lolobata National Park Office, interview).

Hashtag is a creative way carried out by the Twitter community to build collective awareness about a particular issue or problem. In the language of Clay Sirky, social media expert from New York University, Hashtag has a powerful power to form a "shared awareness" that can lead to concrete mass movements such as political demonstrations, awareness actions, social campaigns, and so on. When shared awareness about social issues has felt the urgency of the community and reached its tipping point, then the virus about the issue will spread quickly and crystallize into a mass scale movement on a large scale [9].

\section{Conclusions}

Efforts to prevent the use of endemic animals in North Maluku, the North Maluku Aketajawe National Park Conservation Center conducted a social campaign by utilizing social media through the hashtag. The hashtag or hash movement (\#) is an alternative social campaign to spread ideas through social media. The strategy was carried out because of attention to the rapid development of the internet and the increasingly rapid use of social media. with this strategy it is believed to be able to help them in terms of preservation of endemic animals protected by law.

\section{References}

[1] Kompas.com, "Perdagangan Liar 85 Ekor Burung Langka di Maluku Utara," 2019. .

[2] O. U. Effendy, Ilmu Komunikasi Teori dan Praktek. 2007.

[3] M. R. Colgate and P. J. Danaher, "Implementing a customer relationship strategy: The asymmetric impact of poor versus excellent execution," J. Acad. Mark. Sci., vol. 28, no. 3, pp. 375-387, 2000.

[4] E. M. Rogers and J. D. Storey, "Communication campaigns," 1987.

[5] R. M. Perloff, The dynamics of persuasion: communication and attitudes in the twenty-first century. Routledge, 2010.

[6] A. Venus, S. Rema Karyanti, and J. Rakhmat, Manajemen kampanye: panduan teoritis dan praktis dalam mengefektifkan kampanye komunikasi. Simbiosa Rekatama Media, 2004.

[7] A. Liliweri, "Komunikasi Serba Ada Serba Makna, edisi pertama cetakan ke-1," Kencana Prenada Media Group. Jakarta, 2011.

[8] D. R. Hapsari, "Peran Media Baru Dalam Gerakan Sosial," Demokr. Dalam Ruang Virtual, 2014.

[9] Yuswohady, "hastag gerakan massa." . 